\title{
FOURTH ANNUAL MAY DAY COUNT SASKATOON NATURAL HISTORY SOCIETY, MAY 23, 1960
}

May 23 was far from ideal weatherwise, with heavy showers falling throughout the day and the temperature at a constant $50^{\circ}$. Parts of the river bank at Moon Lake,, normally covered in the May counts, had to be neglected this time. Fourteen observers in 3 parties identified 99 species, 13 fewer than in 1959 when we set an all-time record of 112 species in one day.

The list of birds seen follows. Last year's totals are given in brackets.

SPECIES LIST: Horned Grebe, 21 (2); Eared Grebe, 6 (1); Pied-billed Grebe, 4 (0); Mallard, 92 (114); Gadwall, 5 (15); Pintail, 23 (48); Green-winged Teal, 4 (2); Blue-winged Teal, 10 (72); Ameriian Widgeon, 19 (15); Shoveter, 25 (32); Redhead, 2 (1); Canvasiback, 17 (16); Lesser Scaup, 50 (22); Ruddy Duck, 8 (2); Red-tailed Hawk, 1 (3); Ferruginous Hawk, 1 (0); Mansh Hawk, 5 (12); Pigeon Hawk, 3 (1); Sparrow Hawk, 2 (1); Sharp-tailed Grouse. 2 (3); Ring-necked Pheasant, 6 (14); Sora, 2 (0); American Ccot, 55 (37); Killdeer, 12 (38); Spotted Sandpiper, 1 (5); Solitary Sandpiper, 1 (0); Willet, 9 (17); Lesser Yellowlegs 5 (5); Pecisoral Sandpiper, 17 (34); White-rumped Sandpiper, 2 (1); Baird's Sandpiper, 60 (15); Least Sandpiper, 15 (54); Marbled Godwit, 1 (7); Sanderling, 1 (10); Wilson's Phalarope, 18 (74); California Gull,
50 (6); Ring-b:1led Gull, 110 (56); Franklin's Gull, 76 (52); Black Tern, 119 (22); Rock Dove, 24 (not counted in 1959); Mourning Dove, 29 (62); Great Horned Owl, 3 (1); Eurrcwing Owl, 1 (0); Ruby-throated Hummingbird, 1 (0); Yellow-shafter Flicker, 3 (16); Hairy Wecdpecker, 1 (2); Eastern Kingbird, 14 (18); Eastern Phoebe, 2 (2); Least Flycatsher, 26 (38); Horned Lark, 14 (9); Tree Sparrow, 16 (17); Bank Sparrow, 6 (12); Barn Swallow, 41 (13); Blue Jay, 2 (0): Blask-billed Magpie, 34 (4s); Common Crow, 71 (67); Black-capped Chickadee, 10 (3); House Wren, 14 (11); Cattird, 7 (2); Brown Thrasher, 26 (8); Robin, 33 (94); Swainson's Thrush, 18 (1); Veery, 1 (5); Mounitain Eluebird, 7 (22); Rubycrowned Kinglet, 1 (0); Sprague's Pipit, 4 (3); Loggerhead Shrike, 3 (11); Starling, 29 (35); Red-eyed Vireo, 1 (0); Warbling Vireo, 4 (5); Tennessee Warbler, 2 (3); Yellow Warbler, 49 (67); Magnolia Warbler, 1 (0); Cape May Warbler, 1 (0); Black-throated Green Warbler, 2 (0); Ovenbiri, 2 (0); Mcurning Warbler, 1. (0); Yellowthroat, 1 (2); Redstart, 3 (3); House Sparrow, 162 (323); Western Meadowlark, 49 (150); Yellow-headed Blackbird, 39 (33); Redwinged Blackbind, 111 (64); Ba!timore Oriole, 18 (11); Brewer's Blackbird, 79 (115); Conımon Grackle, 24 (23); Cowbind, 28 (48); Purple Finsh, 1 (0); American Gcldfinch, 12 (5); Rufous-sided Towhee, 9 (16); Savannah Sparrow, 26 (19); Vesper Sparrow, 59 (115); Chipping Sparrow, 24 (24); Clay-colored Sparrow, 67 (153); Harris' Sparrow, 1 (0); White-crowned Sparrow, 2 (0); Whitethroated Sparrow, 3 (1); Song Sparrow, 73 (35). Compiler: Frank Roy, Saskatoon.

\section{BIRDS OF SPECIAL INTEREST IN THE SASKATOON AREA, SPRING, 1960}

by Frank Roy, Saskatoon

Blue Goose-further records for Goose Lake (see Blue Jay, XVIII: 78) -13 seen on April 30; 12 on May 7. In both cases in company of Snow Geese. B. Gollop.

Rough-legged Hawk-a heavier flight of these hawks this spring than in any previous year. On several field trips they were the most common buteo observed. The migration lasted from April 2 to April 30.

Turkey Vulture-an erratic wanderer in this area. One observed on a sandpit in the South Saskatchewan River, May 7, 1960. R Folker.

Long-billed Curlew-the first record within the immediate vicinity of Saskatoon-one adult, 14 miles southwest of the city, May 6, 1960. F. Roy.
American Avocet-particularly numerous this spring along the shores of the alkali lakes. A maximum count of 135 birds at Porter Lake, northeast of Saskatoon, May 29, 1960. B. Gollop.

Dunlin-first Saskatoon record; three observed at Burke Lake, 15 miles east of Saskatoon, May 25. R. Folker, J. Hogg, F. Roy.

Dowitchers, Lesser Yellowlegs, Greater Yellowlegs-late record, June 25, 1960, at a slough 3 miles northeast of Saskatoon: 2 Dowitchers, 6 Lesser Yellowlegs, 1 Greater Yellowleg. B. Gollop.

Burrowing Owl-rarely recorded at Saskatoon. One, just west of the city, May 23, 1960. R. Bremner, F. Roy.

Yellow-bellied Sapsucker and Purple Finch-unusually heavy spring 
migration for both these species. At least three Purple Finches hit picture windows and were brought for identification.

Bobolink-always scarce and locial, have been located in at least six areas within a $30-$ mile radius of Saskatoon. Largest colony- 12 males-6 miles north and 4 miles west of Saskatoon. B. Gollop.
Lark Bunting-first Saskatoon records. Five males near the Forestry Farm, June 8 and 10, 1960. B. Gollop. One on Highway \#5, 13 miles easit of city. R. Folker.

Chestnut-collared Longspur - first Saskatoon $r \in$ cord-small colony in pasture, just west of Burke Lake, 15 miles east of Saskatoon. Further study will be made of these birds. R. Folker, J. Hogg, F. Roy.

\section{INFLUX OF LARK BUNTINGS AT HAWARDEN}

\section{by Harold Kvinge, Hawarden}

We have had an influx of Lark Buntings into this area this summer. There are perhaps a dozen pairs just northwest of our buildings. I presume they are nesting as they have been around for some weeks, although I have not so far found any nests (up to July 15). This is the largest concenitration of these birds in this district since maybe 1937 when they were all around here.

EDITOR'S NOTE: The movement cf Lark Buntings northward into south-central Saskat-

\begin{abstract}
chewan during the past two years has been noted with interest by birders in various, districts. A year ago in the BIue Jay (XVII:129) we printed several reports of the increase of Lark Buntings in 1959 in areas where they had been scarce for some years. This year I have sean them ccmmonly around Regina where, until they reappeared in small number's !ast year, they have been more or less absent sin ze the thirties, at which time they were considered a common breeding resident. At Moose Jaw, too, I have ncted that they seem to be as common this year as during the thirties. North of Hawarden where Mr. Kvinge reports them as abundant, the Saskatoon Natural History Society is reporting Lark Buntings for the first time this year (see previous article in this issue by Frank Roy).
\end{abstract}

\section{A REPORT ON SPRING MIGRATION IN THE REGINA AREA, 1960}

Again this year members of the staff of the Saskatchewan Museum of Natural History and of the Bird Group of the Regina Natural History Society co-operated in a study of spring migration in the Regina area. Records submitted to the Museum and filed by Frank Brazier have been used as the basis for the following list of early arrival dates. A few additional dates were submitted to Margaret Belcher by members of the Bird Group and these have also been incorporated in the list.

\section{SPRING ARRIVAL DATES, 1960}

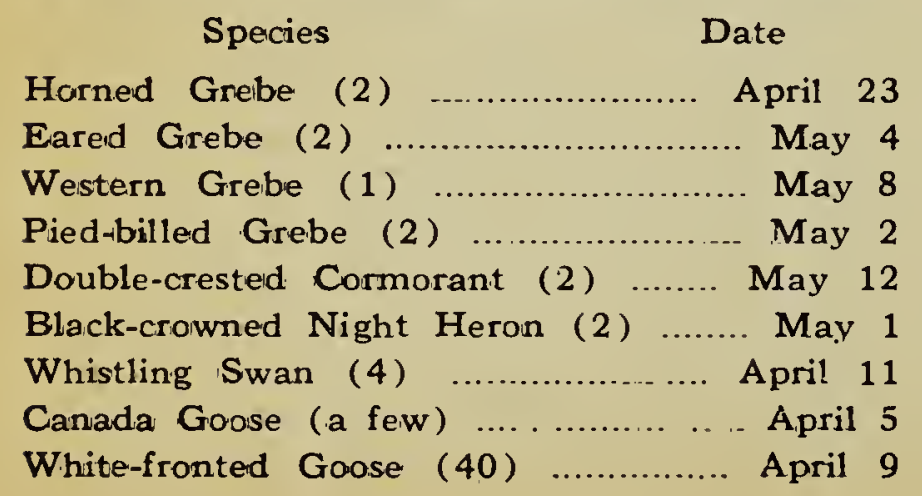

Snow Goose ............................. April 20 Blue Goose (2) ..................... April 9

Gadwall (4) ........................ April 23

Pintail (23) ............................ March 31

Green-winged Teal ........................ April 14

Blue-winged Teal (2) ................ April 21

American Widgeon ....................... April 7

Shcveler (6) ........................ April 10

Redhead. (2) ........................... April 10

Ring-necked Duck (2) ............... April 17

Canvasback (1) ...................... April 8

Lesser Scaup (14) .................... April 10

Common Goldeneye (5) ................. April 1

Bufflehead .............................. April 17

Camman Merganser (8) ............. March 31

Red-breasted Merganser (1) .......... April 10

Sharp-shinned Hawk (1) ............. April 12

Marsh Hawk (1) ....................... April 6

Cooper's Hawk (1) ........................ April 12

Red-tailed Hawk (1) .................... April 9

Brcad-winged Hawk (1) ................. May 3

Rough-legged Hawk (1) .............. March 27

Ferruginous Hawk (1) ..................... May 6

Bald Eagle (1) .......................... April 11

Sparrow Hawk (1) ....................... April 11

Sandhill Crane (50) .................... April 14

American Coot (1) ................ April 15 